\section{Space programme in disarray}

\section{Paris}

THE Soviet space programme is beginning to crack under the strain of a national economy in deepening crisis, according to Soviet officials.

Once shielded by the military, showcase space programmes such as the Buran space shuttle and the Energia heavy-lift launcher can no longer count on the armed forces now that East-West relations are warming. The faltering attempts at decentralization and a free-market economy under Soviet President Mikhail Gorbachev are considered threats to a dynamic Soviet space effort. Glasnost and perestroika, it seems, will not necessarily be good news for the world's leading manned-space programme.

Yuri Rhyzov, chairman of the Science and Technologies Committee of the Supreme Soviet, or parliament, offered some provocative insights into these problems recently in Paris.

"The political prestige of the government was always based on space," said Rhyzov, who is also rector of the Moscow Aviation Institute. "In addition, fundamental sciences thrived in the past because of the weapons and space industry. Scientists argued that all this science and space was needed to create new weapons, new rockets and so on. But I have the feeling that the military today is less interested in space."

In particular, military authorities have said publicly that they have no use for Buran - a move that Rhyzov said raises questions about whether the shuttle will ever carry a crew into space.

Modelled on the US space shuttle, Buran was developed in the mid-1970s "as a classified programme to develop mostly military missions", Rhyzov said. It has flown only once, in November 1988 , in an unmanned launch by the Energia vehicle. That was only the second flight for Energia, which has since remained grounded.

Rhyzov and other Soviet space officials visiting the West in recent months have said the Soviet economy is in such disarray that no one can predict when, or whether, Buran or Energia will fly again. "We are now talking about budgets for three and four months instead of annual budgets, to deal with the fact that the system is bankrupt," Rhyzov said. "It is an impossible situation."

The government had initially agreed to support at least two additional Buran flights - one unmanned, the other carrying a crew - but now all that Rhyzov will say of the shuttle programme is, "It has not yet been formally cancelled."

The Mir space station, in orbit since February 1986, appears relatively safe from Moscow's economic turmoil, at least for now. One reason is that Mir has become a source of foreign earnings. A private Japanese television station paid $\$ 12$ million for an eight-day voyage to Mir by a Japanese journalist last December, and the French and German governments have struck similar deals for flights in 1992 .

A major difficulty for the Soviet civilian space programme is that its budget is inseparable from the military space effort. The government's annual space budget is given to legislators in a lump sum, with space-science missions and sending cosmonauts to the Mir space station bound up with telecommunications and spy satellites.

Under Gorbachev's government restructuring in 1988, the Supreme Soviet was supposed to assume greater authority to review government spending, in the manner of legislators in the Western democracies. This is illusory, Rhyzov said, and the Supreme Soviet in many cases "is just a decoration".

Parliamentarians tried to create line items in the space budget, only to find that the government erased them, he said. "Just recently the government cut these lines without the agreement of the parliament. There is concern that in today's very difficult economic situation, space will be the next field where unexpected budget cuts will be carried out. It has already happened in fundamental science and research."

One of the most important developments in Soviet space in the coming years, Rhyzov said, will be the increased independence of the Russian Republic, where most space work is done. Cutting back on the labour-intensive space programme would mean throwing whole towns out of work. Ironically this, rather than the value of the missions themselves, is uppermost in the minds of many in the government when they consider making deep cuts in space funding.

Adding to all these complications is the fact that glasnost and perestroika have not yet shed much light on what the Soviet space programme actually costs. The problem goes beyond the ruble's nonconvertibility.

"A ruble given to a space programme, or a military programme, has a much greater weight than a ruble given even to social programmes," Rhyzov said. Whereas on the black market a ruble has a value of less that US $\$ 0.05$, a military or space-programme ruble "is equal to the dollar, and may be worth even more," he said. Rhyzov said he supported attempts at creating a free-market economy in the Soviet Union, but the first effects of the change have, resulted in a brain drain of space expertise. Peter B. de Selding
Navy made to pay for civil research

\section{Washington}

It may not be the 'peace dividend' that US researchers had been hoping for, but next year could see a subtle shift of funds from the Department of Defense to support civil science. Apparently with the tacit approval of the White House, the Senate appropriations subcommittee that handles the budgets of the National Aeronautics and Space Administration (NASA) and the National Science Foundation (NSF) intends to make the US Navy pay some \$105 million towards NSF's Antarctic science programme. The move is one of a series of creative accounting measures designed to accommodate the more than $\$ 2,000$ million being spent in 1992 on the space station Freedom and minimize its effect on other scientific projects.

The money in question covers the cost of providing logistical support for the US scientists in Antarctica, and the continuing clean-up of US Antarctic bases to conform with recently tightened standards for environmental protection. Navy ships supply US Antarctic bases, and Navy pilots fly the NSF's transport planes, but the NSF has reimbursed the Navy for these costs in the past.

In last year's appropriations bill, the Senate included a similar proposal to shift NSF funding to the Navy, but Richard Darman, director of the White House Office of Management and Budget (OMB), ruled the measure out of order apparently to avoid a precedent that could blur the distinction between defence and civil spending. So it surprised Washington budget watchers that this year OMB has raised no objections to the change. "It seems pretty clear that the Administration is giving it some support," says Joel Whitter, from NSF's legislative affairs division.

The apparent change of heart is generally attributed to the Administration's determination to keep the Freedom project on course, in the face of opposition from the scientific community as well as some members of Congress. The battle fought in the House of Representatives this year over Freedom's funding is expected to be repeated with even greater intensity in the coming years as the annual cost of the project increases.

The funding shift will require the approval of the Senate appropriations subcommittee on defence; assuming that it and the OMB raise no last-minute objections to the change, the exact amount of money to be bled from the Navy to support the NSF should become clear later this year, when the House and the Senate go into conference over the appropriations bill.

Peter Aldhous 